\title{
The relation between the psychological functioning of children with Down syndrome and their urine peptide levels and levels of serum antibodies to food proteins
}

\author{
Egil Nygaard', Karl Ludvig Reichelt' and Joseph F. Fagan² \\ 1 University of Oslo, Norway \\ ${ }^{2}$ Case Western Reserve University, Department of Psychology, USA
}

\begin{abstract}
Aims: To investigate the relation between psychological functioning of subjects with Down syndrome, and their levels of urine peptide and serum antibodies to food proteins. Methods: 55 children with Down syndrome in a cross-sectional study. Psychological functioning was measured by the Stanford-Binet Intelligence Scale: Fourth Edition, McCarthy Scales of Children's Abilities and Fagan's computer based test of novelty preference. Results: The participants, and their siblings, were found to have significantly increased total urine peptide levels. There were no significant correlations between peptide levels and psychological functioning. Significantly increased levels of $\lg G$ activity to gliadin and gluten, and IgA activity to gliadin, gluten and casein were found. There were significant negative correlations (Spearman $r=-0.13$ to $-0.5 \mathrm{I}$ ) between psychological functioning, and $\lg G$ and $\lg A$ activity to gliadin and gluten. Conclusions: $A$ significant relation between antibodies to gluten and psychological functioning was documented. The mechanism and potential causal link are still unknown.
\end{abstract}

Keywords - lgG, IgA, Dietary Proteins, Gluten, Gliadin, Celiac disease, Casomorphin, StanfordBinet test, McCarthy test, Fagan test.

\begin{abstract}
Abbreviations - CNS, central nervous system; df, degrees of freedom; ELISA, enzyme-linked immunosorbent assay; G-score, general cognitive functioning score; HPLC, high pressure liquid chromatography; IgA, immunoglobulin A; IgG, immunoglobulin G; IQ, intelligence quotient; M-score, motor functioning score; OD, optical density; $r$, correlation; SB:FE, Stanford-Binet Intelligence Scale: Fourth Edition; SD, standard deviation.
\end{abstract}

\section{Introduction}

Increased serum levels of antibodies to food proteins in people with Down syndrome (Kanavin et al., 1988; Reichelt KL et al., 1994; Bonamico et al., 1996; Failla et al., 1996; George et al., 1996; Gale et al., 1997; Carlsson et al., 1998), point to an increased transmucosal uptake of proteins from the gut (Scott et al., 1984). Increased uptake of proteins combined with peptidase deficiencies would result in hyperpeptidaemia and usually hyperpeptiduria. The increased transmucosal uptake may also result in an increased uptake of peptides directly from the gut (Gardner, 1994). Gluten, gliadin and casein contain several exorphin sequences (Fukudome \& Yoshikawa, 1992; Nyberg \& Brantl, 1989), some of which, due to their pleated sheet structure, are very immunogenic and resistant to break down (Reichelt et al., 1994). This means that even a low concentration of these food proteins could cause a massive peptide release. Hyperpeptiduria in people with Down syndrome has been found in an earlier study (Shattock et al., 1990), supporting the hypothesis of increased peptide levels in the blood.

Some opioide peptides can be derived from gluten (Fukudome \& Yoshikawa, 1992; Ziodrou et al., 1979), and peptides derived from gluten have been shown to cross the blood-brain barrier (Lorenz, 1990). Some opioids interfere with the pruning process of synapses (Feinberg, 1982/83) and are involved in regulating cell proliferation in the proliferative phase of the developing brain (Zagon \& McLaughlin, 1987). Thus, increased levels of some specific peptides may affect the development of the CNS. The many CNS 
effects related to celiac disease also suggest that the CNS can be negatively affected when food proteins are not sufficiently broken down (Gobbi et al., 1992; Kinney et al., 1982; Cooke \& Smith, 1966; Hadjiwassiliou et al., 1996; Bhatia et al., 1995).

In this study we examine the relation between the psychological functioning of children with Down syndrome, and their urine peptide levels and levels of serum antibodies to certain food proteins.

\section{Method}

\section{Participants}

Invitations were sent to all parents of children with Down syndrome at ages between 4 and 11 in five counties in Norway. Of the approximately 110 families invited to participate in the study, 55 consented.

The mean age was 86.1 months ( $S D=23.4$ months). Sex ratio (26 girls, 29 boys) was as expected (Steele, 1996). In contrast to an expected $20 \%$ (Statistisk Sentralbyrå, 1996), $70.4 \%$ of the parents had university level education. A total of 25 children had medical complications which could have influenced their cognitive/motor functioning. These included cardiac illnesses (9 children), respiratory illnesses (5), history of serious infections (2), celiac disease (2), substantial hearing impairment (2), hypothyroidism (2), cataract, absent colon and allergies. Six of the children were on a diet which could have influenced their levels of antibodies to food proteins ( 3 were on a gluten free diet).

\section{Procedure}

The Stanford-Binet Intelligence Scale: Fourth Edition (Thorndike, et al. 1986) was administered. Recommended subtest battery consisting of the following eight subtests was used (Sattler, 1992): Vocabulary, Comprehension, Absurdities, Pattern Analysis, Copying, Quantitative, Bead Memory and Memory For Sentences. To preserve the high variability from the test results, raw scores of zero were included instead of being excluded.

All of the subtests included in the Motor Scale of the $\mathrm{McCa}$ rthy Scales of Children's Abilities (McCarthy, 1972) were administered. These were: Leg Co-ordination, Arm Coordination, Imitative Action, Draw-A-Design and Draw-AChild.

The computer based Fagan test of novelty preference for children above 2 years of age (Fagan \& Vasen, 1997) was administered. This test is thought to measure capacity to process information, and has been found to be predictive of later intellectual achievement (Fagan \& Vasen, 1997). A total of 20 "novelty problems" were presented. The problems compared the time that the child spent looking at a novel face to the time spent looking at a familiarised face. The novel and the familiarised faces were digitised and appeared beside each other on a computer screen. Each of the 10 first problems consisted of a 5 second familiarisation period and two 2 second matching periods with left-right position reversed between each period (immediate recogni- tion memory). In the next 10 problems a novel face was presented for two 2 second periods together with a face that had been shown in the earlier problems (delayed recognition memory). The average interobserver reliability in the measurement of differential fixation is 0.94 (Fagan \& Detterman, 1992).

Testing of psychological functioning was performed blind to the results of the urine and serum analyses, and viceversa.

Urine samples (94\% morning-urine) were collected and frozen for later analysis according to the method described by Reichelt WH et al. (1997) based on reversed phase high pressure liquid chromatography (HPLC).

As a control group, urine samples from 44 siblings (31 boys and 13 girls) (mean age $=92.7$ months and $\mathrm{SD}=35.3$ months) were analysed in the same way.

Blood-samples were taken by different laboratories and sent to Nycomed, Oslo, where IgG and IgA antibodies to food proteins were measured as described by Scott et al. (1985a) using an enzyme-linked immunosorbent assay (ELISA). The following antibodies were tested: IgG to gliadin and gluten, IgA to gliadin, gluten, a-lactalbumin, b-lactoglobulin, casein and ovalbumin. In participants whose antibody levels to food proteins indicated possible celiac disease, serum antibodies against endomysium were tested (Bonamico et al., 1996; Scott et al., 1985a; Cataldo et al., 1995), and an intestinal biopsy was performed to confirm diagnosis of celiac disease.

\section{Statistical Procedures}

The Stanford-Binet Intelligence Scale: Fourth Edition (SB:FE) and McCarthy raw scores were transformed into $\mathrm{Z}$-scores and averaged to compute a general cognitive functioning score (G-score) based on SB:FE and a motor functioning score (M-score) based on McCarthy.

Partial correlation, controlled for sex and age based on ranked results, was used (approximate to Spearman correlation). One subject scored very low on all measurements of psychological functioning, which greatly influenced all results. Therefore, all discussions are based on results without extreme values $(\mathrm{SD}>3)$. Results with and without extreme scores are shown.

SPSS for MS WINDOWS Release 6.1 was used for all statistics.

\section{Results}

IQs (SB:FE) ranged from 36 to 72 , with a mean of $51.9(\mathrm{SD}=10.1)$. These scores were significantly higher $(\mathrm{t}$-value $=2.6 \mathrm{p}<0.02)$ than earlier findings reported by Bower and Hayes (1995) who reported a mean of 45.9 $(\mathrm{SD}=8.9)$. This difference is probably due to a higher mean age in their study (mean=132.4 months $\mathrm{SD}=43.6$ ). The present study found the same profile in Area Standard Age Scores as reported by Bower and Hayes (1995).

There was a significant negative correlation between age and the SB:FE Composite Score (Pearson $r=-0.54 \mathrm{p}<0.001$ ). 


\begin{tabular}{|c|c|c|c|c|c|c|c|}
\hline Measure & $\mathbf{N}$ & Mean & SD & Range & $\begin{array}{l}\text { Upper normal } \\
\text { limits }\end{array}$ & $\begin{array}{l}\mathrm{N} \text { above } \\
\text { normal }\end{array}$ & $\begin{array}{l}\text { chi-square } \\
\text { sign. }\end{array}$ \\
\hline $\begin{array}{l}\text { Total peptide levels } \\
\text { in urine }\end{array}$ & 55 & 548.50 & 445.00 & $224-3440$ & 374.90 & 40 & $\mathrm{p}<0.001$ \\
\hline $\begin{array}{l}\text { Total peptide levels } \\
\text { in urine of siblings }\end{array}$ & 44 & 482.20 & 161.20 & $198-850$ & 374.90 & 32 & $\mathrm{p}<0.001$ \\
\hline IgG gliadin & 55 & 1.33 & 0.40 & $0.18-1.90$ & 1.69 & 9 & $p<0.001$ \\
\hline IgG gluten & 55 & 1.35 & 0.36 & $0.22-1.84$ & 1.69 & 7 & $p<0.01$ \\
\hline IgA gliadin & 55 & 0.59 & 0.77 & $0.01-3.56$ & 0.39 & 19 & $p<0.001$ \\
\hline IgA gluten & 55 & 0.73 & 0.82 & $0.01-3.47$ & 0.39 & 26 & $p<0.001$ \\
\hline IgA lactalbumin & 55 & 0.01 & 0.01 & $0.01-0.09$ & 0.29 & 0 & n.s. \\
\hline IgA lactoglobulin & 55 & 0.14 & 0.27 & $0.01-1.29$ & 0.39 & 5 & n.s. \\
\hline $\lg A$ casein & 55 & 0.78 & 0.77 & $0.01-3.07$ & 0.79 & 16 & $p<0.001$ \\
\hline IgA ovalbumin & 55 & 0.05 & 0.12 & $0.01-0.63$ & 0.39 & 2 & n.s. \\
\hline
\end{tabular}

Oneway ANOVA by quartile age groups gave the same results $(\mathrm{F}=10.6 \mathrm{df}=54 \mathrm{p}<0.0001)$. A decline in IQ-scores with increasing age is common among children with Down syndrome (Rogers \& Coleman, 1992). Motor functioning score expressed as a percentage of chronological age based on McCarthy Motor Scale gave similar correlation with age $(\mathrm{r}=-0.55$ and $\mathrm{p}<0.001)$. By correcting raw scores for age based on normative data, we would introduce an over-correction of age and an unnecessary error. We chose therefore to base our analysis on the raw scores, transformed into $\mathrm{Z}$-scores and averaged to compute a G-score based on SB:FE and a M-score based on McCarthy. The G-score had a reliability alpha $=0.94$, and the $\mathrm{M}$-score had an alpha $=$ 0.87 .

Socio-economic status measured by education (Statistisk Sentralbyrå, 1989) and profession (Statistisk Sentralbyrå, 1984), did not correlate significantly with either cognitive/ motor functioning or any other measure. There were significant sex differences for IgG activity to gliadin ( $\mathrm{t}$-value $=3.49$ $\mathrm{p}=0.001$ ) and gluten ( $\mathrm{t}$-value=3.61 $\mathrm{p}=0.001$ ). Neither having medical complications nor being on a diet made any significant difference for peptide levels, antibodies to food proteins or psychological functioning (Mann-Whitney U test and t-test). This could be due to the broad spectrum of medical complications and the low number of children on a diet. As expected, peptide levels in urine and all $\operatorname{IgG}$ and IgA levels were skewed.

Mean novelty scores on the Fagan test were 54.04\% $(\mathrm{SD}=6.7)$ for immediate presentation and $50.8 \%(\mathrm{SD}=6.4)$ for delayed presentation $(\mathrm{t}=2.84 \mathrm{p}<0.01)$. Both values were significantly lower than expected compared to children without Down syndrome $(\mathrm{t}$-immediate $=-2.5 \mathrm{p}<0.02)$ $(\mathrm{t}$-delayed=-2.2 $\mathrm{p}<0.05) \quad($ Fagan \& Vasen, 1997). These results are almost identical to a study of 41 subjects with Rett syndrome (Tetzchner et al., 1996). Immediate recognition memory had a reliability alpha $=0.20$, and the delayed recognition memory had an alpha $=0.03$. Both the low average and the low internal consistency indicate that the

\begin{tabular}{|c|c|c|c|c|c|c|c|c|c|}
\hline \multirow{2}{*}{$\begin{array}{l}\text { Total peptide } \\
\text { levels in urine }\end{array}$} & \multirow{2}{*}{$\begin{array}{l}\text { Df } \\
\text { with/ } \\
\text { without } \\
\text { extremes } \\
\\
51 / 49\end{array}$} & \multicolumn{2}{|c|}{$\begin{array}{l}\text { Part. Corr. } \\
\text { Ranked Scores } \\
\text { McCarthy Motor } \\
\text { Functioning } \\
\text { with/ without } \\
\text { extremes }\end{array}$} & \multicolumn{2}{|c|}{$\begin{array}{l}\text { Part. Corr. } \\
\text { Ranked Scores } \\
\text { SB:FE Cogn. } \\
\text { Functioning } \\
\text { with/ without } \\
\text { extremes }\end{array}$} & \multicolumn{2}{|c|}{$\begin{array}{l}\text { Part. Corr } \\
\text { Ranked Scores } \\
\text { Fagan Test } \\
\text { Immediate } \\
\text { with/ without } \\
\text { extremes }\end{array}$} & \multicolumn{2}{|c|}{$\begin{array}{l}\text { Part. Corr. } \\
\text { Ranked Scores } \\
\text { Fagan Test } \\
\text { Delayed } \\
\text { with/ without } \\
\text { extremes }\end{array}$} \\
\hline & & & & & 0.11 & 0.16 & 0.17 & $-0.26 *$ & -0.20 \\
\hline IgG gliadin & $51 / 50$ & -0.13 & -0.21 & -0.17 & $-0.27 \#$ & $-0.45 \dagger$ & $-0.48 \dagger$ & -0.12 & -0.16 \\
\hline IgG gluten & $51 / 50$ & & -0.15 & -0.18 & $-0.28 \#$ & $-0.45 t$ & $-0.48+$ & -0.15 & -0.18 \\
\hline IgA gliadin & $51 / 49$ & -0.16 & $-0.24^{*}$ & -0.20 & $-0.29 \#$ & $-0.43 \dagger$ & $-0.44 \dagger$ & -0.16 & -0.14 \\
\hline IgA gluten & $51 / 49$ & -0.19 & $-0.29 \#$ & $-0.23^{*}$ & $-0.33 \#$ & $-0.49+$ & $-0.51+$ & -0.14 & -0.13 \\
\hline IgA lactalbumin & $51 / 48$ & 0.17 & 0.13 & 0.15 & 0.12 & & & -0.20 & $-0.27^{*}$ \\
\hline IgA lactoglobulin & $51 / 48$ & & -0.10 & & -0.10 & -0.16 & -0.21 & & \\
\hline IgA casein & $51 / 50$ & -0.14 & -0.21 & & -0.16 & -0.14 & -0.16 & & \\
\hline IgA ovalbumin & $51 / 48$ & & & & & -0.15 & $-0.25^{*}$ & & \\
\hline \multicolumn{10}{|c|}{$\begin{array}{l}\text { Table 2. Partial correlations based on ranked scores, controlled for age and sex, of children with Down syndrome } \\
\text { between peptide levels and levels of antibodies to food proteins, with motor/cognitive functioning and Fagan's test } \\
\text { of novelty. Only correlations greater than or equal to } 0.10 \text { are shown. *means significant with } p<=0.1 \text {. \# means } \\
\text { significant with } p<=0.05 \text {. }+ \text { means significant with } p<=0.005\end{array}$} \\
\hline
\end{tabular}


delayed task was too difficult for the participants. There was no significant correlation between immediate and delayed novelty scores. There were also no significant correlations between results on the Fagan test, and on SB:FE and McCarthy respectively.

The children with Down syndrome did not have significantly increased levels of urinary peptides when compared with their siblings (Mann-Whitney U test) (Table 1 ). Both groups had significantly increased peptide levels when compared to an earlier sample of 117 normal children (Reichelt et al., 1997) (t-DS $=4.44 \mathrm{p}<0.01)(\mathrm{t}$-siblings $=5.85 \mathrm{p}<0.01)$ (Table 1).

31 of 55 children with Down syndrome had levels of antibodies to food proteins above the upper normal limit (Scott et al., 1985b). This was significant for the following antibodies: IgG to gliadin and gluten, IgA to gliadin, gluten and casein (Table 1). Two subjects had previously been diagnosed with celiac disease and were on a gluten free diet. Endomysium antibodies and intestinal biopsy confirmed untreated celiac disease in two further subjects.

No significant correlations between total urine peptide levels, and cognitive/motor functioning or novelty preference were found (Table 2). None of the known individual urinary peptides (indolylacrylylglycin, casomorphinb 1-8, casomorphinb 1-7, casomorphinb 1-5, casomorphinb 1-4 and casomorphinb 1-5 amide) correlated significantly with any of the measures obtained of psychological functioning.

Significant negative correlations between G-score, and IgG and IgA activity to gliadin and gluten were found. In addition, a significant negative correlation between M-score, and $\operatorname{IgA}$ activity to gluten was found. There were also non significant negative correlations between $\mathrm{M}$-score, and IgG activity to gliadin and gluten and $\operatorname{IgA}$ activity to gliadin (Table 2).

There were highly significant negative correlations between IgG and IgA activity to gliadin and gluten, and immediate recognition memory on the Fagan test (Table 2).

The fact that all correlations between antibodies to gluten/ gliadin and psychological functioning were negative, the majority of them being significant, makes it very unlikely that the findings are by chance.

There was a non-significant negative correlation between delayed recognition memory and IgA activity to lactalbumin (Table 2). In regard to $\operatorname{IgA}$ activity to lactalbumin, only seven children had optical density (OD) levels above 0.01 . Therefore these results are uncertain.

There were no significant correlations between delayed recognition memory and any $\operatorname{IgA}$ or IgG activities, probably because this task was too difficult for many of the participants.

No significant correlations were found between psychological functioning and IgA activity to lactalbumin, lactoglobulin, casein or ovalbumin.

\section{Discussion}

The present study documents hyperpeptiduria in children with Down syndrome and their siblings, indicating a probable increased uptake of proteins and peptides from the gut. Further independent studies investigating familial links are required.

Neither total urine peptide level nor specific peptide levels correlated significantly with psychological functioning. The lack of significant correlations between the specific casomorphins and psychological findings is supported by a similar lack of significant correlations between the milk based serum antibodies (lactalbumin, lactoglobulin and casein) and psychological functioning. Unfortunately it is not yet possible to analyse the gluten/gliadin based urinary peptide levels separately.

This report shows that children with Down syndrome have increased levels of antibodies to food proteins, and thus confirms earlier findings (Kanavin et al., 1988; Reichelt KL et al., 1994; Bonamico et al., 1996; Failla et al., 1996; George et al., 1996; Gale et al., 1997; Carlsson et al., 1998). No studies have investigated whether siblings also have increased levels of serum antibodies to food proteins. Today there is no reason to expect that siblings of children with Down syndrome are negatively affected by their increased urinary peptide levels or possible raised antibodies to specific food proteins. We suggest that children with Down syndrome have a combination of increased levels of exogenous proteins/peptides and a vulnerability to these proteins/peptides which is different to people without Down syndrome.

The significant negative correlations found between psychological functioning, and IgG and IgA activity to gliadin and gluten do not prove a causal relation. However, we suggest that these results could be explained in part by the model in Figure 1.

The increased $\operatorname{Ig}$ A activity to food proteins seen in children with Down syndrome suggests a transmucosal defect with increased protein uptake from the gut (Reichelt WH et al., 1997; Marsh, 1995; Roitt, 1997). A transmucosal defect, possibly combined with a protease/peptidase defect, would result in an increased circulation of proteins and peptides in the blood (Gardner, 1994). Increased levels of circulating foreign proteins results in increased IgG activity to gluten (Roitt, 1997). Hyperpeptiduria found in the subjects (Table 1) supports the hypothesis of increased circulation of peptides in the blood. Some opioide peptides can be derived from gluten (Fukudome \& Yoshikawa, 1992; Nyberg \& Brantl, 1989; Ziodrou et al., 1979), and peptides derived from gluten have been shown to cross the blood-brain barrier (Lorenz, 1990). Very similar opioide peptides derived from casein (Nyberg \& Brantl, 1989) also cross the blood-brain barrier (Ermisch, et al. 1983) and may be associated with postpartum psychosis (Lindström $e t$ al., 1984). It has also been shown that opioide systems can regulate both the pruning of synapses (Feinberg, 1982/83) and the proliferation of cells (Zagon \& McLaughlin, 1987) 


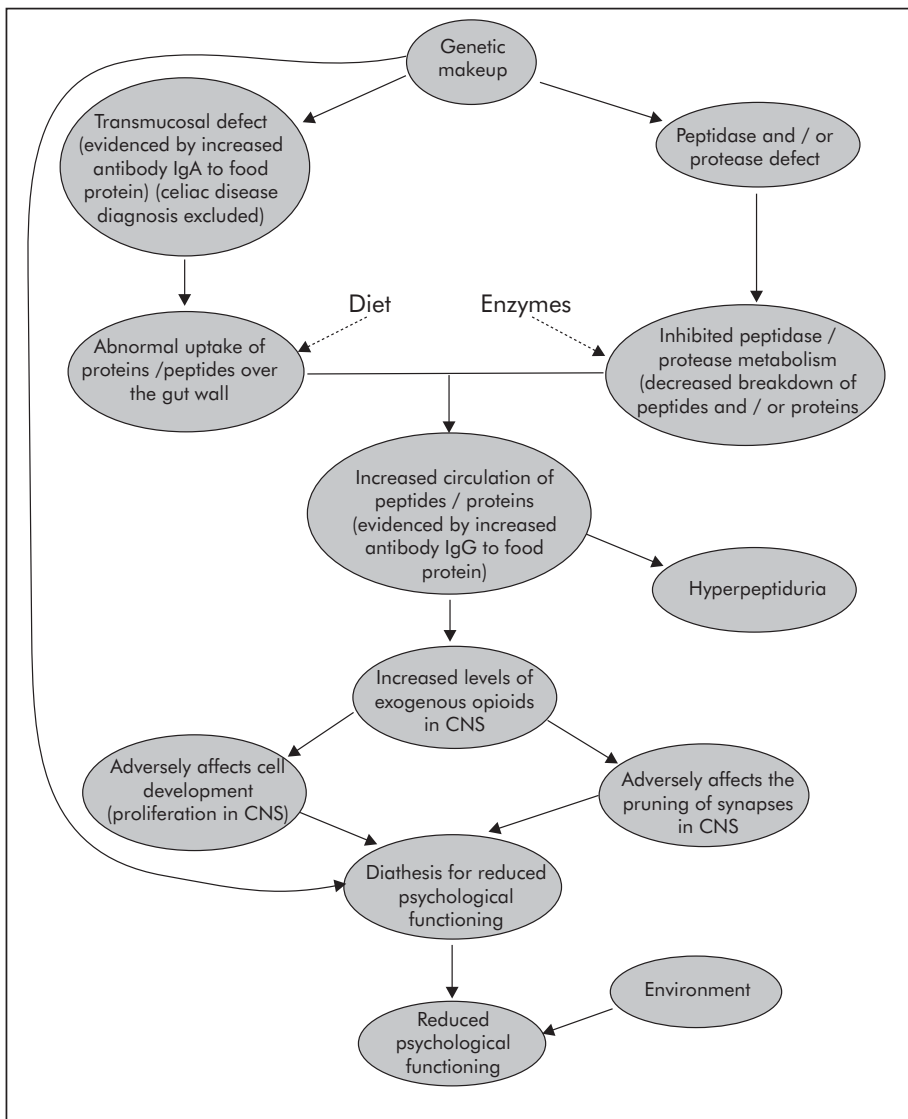

Figure I. Suggestion of etiological model

in the CNS in rats. A possible continuous exposure to neurotoxic (Paganuzzi et al., 1985) proteins and peptides (opioids) combined with a genetic vulnerability may therefore in part explain the diathesis for psychological deficit seen in children with Down syndrome. The genetic makeup does of course also influence this chain through several other mechanisms. In addition everything a child experiences throughout life (environment) will greatly influence how he or she will actually function in daily life.

The Fagan test is thought to measure a child's basic processing ability. This capacity is not influenced by the child's rearing environment, but it can be influenced by toxic factors that directly affect the CNS (Fagan \& Vasen, 1997). We therefore regard the Fagan test as an indicator of the biological basis for psychological development. The SB:FE and McCarthy are measurements of psychological functioning which is influenced by the environment. Bearing this in mind, it is of interest to note that the Fagan test, supporting our hypothesis, showed the highest negative correlations ( $\mathrm{r}=-0.44$ to $-0.5 \mathrm{l}$ ) with antibodies to gliadin/ gluten. SB:FE had a weaker relation $(r=-0.27$ to -0.33$)$. McCarthy correlated even less with antibodies to gliadin/ gluten $(\mathrm{r}=-0.15$ to -0.29$)$, which could be explained by the lower reliability of this test.

There could be cause for scepticism due to the low internal reliability of the Fagan test (Alpha $=0.20$ for immediate recognition) combined with high correlations with antibodies to gluten/gliadin $(\mathrm{r}=-0.44$ to $-0.5 \mathrm{l})$. It is typical for this test that its predictive validity is higher than its reliability (McCall \& Carriger, 1993). This could be explained by the fact that maximum predictive correlation may be expressed as the square root of the product of the two reliabilities. If the measurement of antibodies had a reliability of 0.95 , maximum predictive validity would be 0.44 . An explanation for the findings of even higher correlations could be that more than one process was assessed when using the Fagan test (McCall \& Carriger, 1993). The findings could also be partly coincidental.

Since IgG activity is seen as a measurement of circulation in blood, and IgA activity as a measurement of transmucosal defect (Roitt, 1997), one would expect that $\mathrm{IgG}$ activity would correlate higher than $\operatorname{IgA}$ activity with the psychological tests. This was not the case. The correlation between $\operatorname{IgA}$ and IgG activity $(r=0.56)$ was not high enough to explain this.

Even though most of the children in the present study did not have celiac disease, it is relevant to compare our results with studies of other groups of people with gluten sensitivity. As Marsh (1995, p.12) stated, "gluten sensitivity should be considered as a state of heightened immunological responsiveness ( $\mathrm{T}$ - and B-cell-based) to ingested gluten proteins in genetically-predisposed individuals". It is also important to remember that the frequency of celiac disease in people with Down syndrome is much higher than in the general population (Failla et al., 1996; George et al., 1996; Gale et al., 1997; Morris et al., 1997; Carlsson et al., 1998). A connection between gluten sensitivity and neurological disorders has been reported for patients with celiac disease (Gobbi et al., 1992; Kinney et al., 1982; Cooke \& Smith, 1966; Bhatia et al., 1995), as well as for patients with neurological dysfunction of unknown cause (Gobbi et al., 1992; Hadjiwassiliou et al., 1996). It has also been shown that children with celiac disease in remission can get lasting pathological EEG changes when exposed to gluten for more than 5 months (Paul et al., 1985).

A gluten free diet does not only help people with celiac disease to avoid their normal symptoms. An early diet can in some cases also help in avoiding epileptic seizures and neurological disorders in celiac patients (Gobbi et al., 1992). Moreover, several longitudinal studies show that a gluten free diet may help to improve the psychological functioning of some patients with autism (Reichelt WH et al., 1997; Shattock, 1995; Whiteley et al., 1997; Lucarelli et al., 1995; Cade JR, personal communication; Howlin, 1997), and possibly a subset of patients with schizophrenia (Gardner, 1994; Lorenz, 1990).

Even though the current study found a significant negative correlation between antibodies to gluten and psychological functioning, one must be careful to draw conclusions about a causal link. Assuming there is a causal link, we do not know all the metabolic steps, knowledge which may be essential for finding effective individualised interventions 
(either dietary or enzyme based) for the children. Due to the rapid development of the brain before birth and during the first 2 years, dietary intervention may have to start at a very early age in order to have an effect. Most of the aberrant brain development in children with Down syndrome occurs after birth (Rogers \& Coleman, 1992), giving hope that early interventions could help.

Due to the complexity of Down syndrome, gluten is only one of several components which may influence the psychological development of children with Down syndrome. However, we hope that the fact that gluten is a commonly ingested food protein, combined with the high correlations found in this study, will motivate further interdisciplinary research and longitudinal studies in this area.

\section{Acknowledgements}

This work was supported by the Høyesterettsadvokat Eckbos foundation, the Åsa Gruda Skards foundation, the Sigurd K. Thoresen foundation and by the Professor Dr. Mourly Vold and sister's foundation. We extend thanks to Professor Lars Smith for his critical review of the study and to all the families who participated in the study.

\section{Correspondence}

Egil Nygaard, Harreschousvei 7, 1338 Sandvika, Norway. Telephone +4767564357• Email:

egil.nygaard@baerum.kommune.no

\section{References}

Bhatia,K.P., Brown, P., Gregory, R., Lennox, G.G., Manji, H., Thompson, P.D., Ellison, D.W. \& Marsden, C.D. (1995). Progressive myoclonic ataxia associated with coeliac disease: The myoclonus is of cortical origin, but the pathology is in the cerebellum. Brain, 118, 1087-1093.

Bonamico, M., Rasore-Quartino, A., Mariani, P., Scartezzini, P., Cerruti, P., Tozzi, M.C., Cingolani, M. \& Gemme, G. (1996). Down syndrome and celiac disease: usefulness of antigliadin and antiendomysium antibodies. Acta Paediatrica, 85, 1503-1505.

Bower, A. \& Hayes, A. (1995). Relations of scores on the Stanford Binet Fourth Edition and Form L-M: Concurrent validation study with children who have mental retardation. American Journal on Mental Retardation, 99(5), 555-563.

Carlsson, A., Axelsson, I., Borulf, S., Bredberg, A., Forslund, M., Lindberg, B., Sjoberg, K. \& Ivarsson, S.A. (1998). Prevalence of IgA-antigliadin antibodies and IgA-antiendomysium antibodies related to celiac disease in children with Down syndrome. Pediatrics, 101(2), 272-275.

Cataldo, F., Ventura, A., Lazzari, R., Balli, F., Nassimbeni, G. \& Marino, V. (1995). Antiendomysium antibodies and coeliac disease: solved and unsolved questions. An Italian multicentre study. Acta Paediatrica, 84, 1125-1131.

Cooke, W.T. \& Smith, W.T. (1966). Neurological disorders associated with adult coeliac disease. Brain, 89, 683-722.

Ermisch, A., Rühle ,H-J., Neubert, K., Hartrodt, B. \& Landgraf, R. (1983). On the blood-brain barrier to peptides: $[3 \mathrm{H}] \mathrm{b}$-Casomorphin- 5 iptake by eighteen brain regions in vivo. Journal of Neurochemistry, 41(5), 1229-1233.
Fagan, J.F. \& Detterman, D.K. (1992). The Fagan Test of Infant Intelligence: a technical summary. Journal of Applied Developmental Psychology, 13, 173-193.

Fagan, J.F. \& Vasen, J.H. (1997). Selective attention to novelty as a measure of information processing across the life span. In J.A. Burack and J.T. Enns (Eds.), Attention, Development and Psychopathology. New York: Guilford Press. pp. 55-73.

Failla, P., Ruberto, C., Pagano, M.C., Lombardo, M., Bottaro, G., Perichon, B., Krishnamoorthy, R., Romano, C. \& Ragusa, A. (1996). Celiac disease in Down's syndrome with HLA serological and molecular studies. Journal of Pediatric Gastroenterology and Nutrition, 23, 303-306.

Feinberg, I. (1982/83). Schizophrenia: Caused by a fault in programmed synaptic elimination during adolescence? Journal of Psychiatric Research, 17(4), 319-334.

Fukudome, S-I. \& Yoshikawa M. (1992). Opioid peptides derived from wheat gluten: their isolation and characterization. Federation of European Biochemical Societies Letters, 296(1), 107-111.

Gale, L., Wimalaratna, H., Brotodiharjo, A. \& Duggan, J.M. (1997). Down's syndrome is strongly associated with coeliac disease. Gut, 40(4), 492-496.

Gardner, M.L.G. (1994). Absorption of Intact Proteins and Peptides. In L.R. Johnson (Ed.), Physiology of the Gastrointestinal Tract, 3rd Ed. New York, Raven Press. pp. 1795-1820.

George, E.K., Mearin, M.L., Bouquet, J., von Blomberg, B.M., Stapel, S.O., van Elburg, R.M., de Graaf, E.A., Hertzberger-ten Cate, R., van Suijlekom-Smith, L.W., Reeser,H.M., et al. (1996). Screening for coeliac disease in Dutch children with associated diseases. Acta Paediatrica. Supplement, 412, 52-53.

Gobbi,G., Bouquet, F., Greco, L., Lambertini, A., Tassinari, C.A., Ventura, A. and Zaniboni, M.G. (1992). Coeliac disease, epilepsy, and cerebral calcifications. Lancet, 340, 439-443.

Hadjiwassiliou, M., Gibson,A., Davies-Jones, G.A.B., Lobo, A.J., Stephenson, T.J. and Milford-Ward, A. (1996).

Does cryptic gluten sensitivity play a part in neurological illness?. Lancet, 347, 369-371.

Howlin, P. (1997). Prognosis in autism: do specialist treatments affect long-term outcome? European Child \& Adolescent Psychiatry, 6, 55-72.

Kanavin, Ø., Scott, H., Fausa, O., Ek, J., Gaarder, P.I. \& Brandtzaeg, P. (1988). Immunological studies of patients with Down's syndrome. Acta Medica Scandinavica, 224, 473-477.

Kinney, H.C., Burger, P.C., Hurwitz, B.J., Hijmans, J.C. \& Grant, J.P. (1982). Degeneration of the central nervous system associated with celiac disease. Journal of the Neurological Sciences, 53, 9-22.

Lindström, L.H., Nyberg, F., Terenius, L., Bauer, K., Besev, G., Gunne, L.M., Lyrenäs, S., Willdeck-Lund, G. \& Lindberg, B. (1984). CSF and Plasma b-CasomorphinLike Opioid Peptides in Postpartum Psychosis. American Journal of Psychiatry, 141, 1059-1066.

Lorenz, K. (1990). Cereals and Schizophrenia. In Y. Pomeranz. Advances in Cereal Science and Technology. St. Paul. pp. 435-469.

Lucarelli, S., Frediani,T., Zingoni, M., Ferruzzi, F., Giardini, O., Quintieri, F., Barbato, M., D'Eufemia, P. and Cardi, 
E. (1995). Food allergy and infantile autism. Panminerva Medica, 37, 137-141.

Marsh, M.N. (1995). The natural history of gluten sensitivity: defining, refining and re-defining. Quarterly Journal of Medicine, 85, 9-13.

McCall, R.B. and Carriger, M.S. (1993). A meta-analysis of infant habituation and recognition memory performance as predictors of later IQ. Child Development, 64, 57-79.

McCarthy, D.A. (1972). Manual for the McCarthy Scales of Children's Abilities. San Antonio: The Psychological Corporation.

Morris, M-A., Biagi, F., Ellis, H.J., Brett, P. and Ciclitira, P.J. (1997). Are Down syndrome and coeliac disease associated? Gut, 41, 724.

Nyberg, F. and Brantl, V. (Ed.) (1989) b-Casomorphins and related peptides. Proceeding from The First International Symposium on b-casomorphins and related peptides; 1989 Sept 8-10; Uppsala, Sweden.

Paganuzzi, A.S., Zucco, F., Cardelli, M., DeAngelis, I., Mattei, R., Pino, A., Rocca, E. and Zampaglioni, F. (1985). Cytotoxic effects of wheat gliadin-derived peptides. Toxicology, 37, 225-232.

Paul, K-D., Henker, J., Todt, H. and Eysold, R. (1985). EEGBefunde bei Zöliakiekranken Kindern in Abhängigkeit von der Ernährung. Zeitschrift fur Klinische Medizin, 40(10), 707-709.

Reichelt, K-L., Lindback, T. and Scott, H. (1994). Increased levels of antibodies to food proteins in Down syndrome. Acta Paediatrica Japonica, 36, 489-492.

Reichelt, K-L., Pedersen, O.S., Liu, Y., Knivsberg, A-M. and Nødland, M. (1997). Possible role of peptides, exorphins and serotonin uptake: Stimulating peptides in autism. In The Autism Research Unit (Ed.) Living and Learning with Autism: Perspectives from the Individual, the Family and the Professional. Collected papers from the conference; 1997 April 7th-9th; University of Durham, UK. pp. 221-231.

Reichelt, W.H., Knivsberg, A-M., Nødland, M., Stensrud, M. and Reichelt, K-L. (1997). Urinary peptide levels and patterns in autistic children from seven countries, and the effect of dietary intervention after 4 years. Developmental Brain Dysfunction, 10, 44-55.

Rogers, P.T. and Coleman, M. (1992). Medical Care in Down Syndrome: A Preventive Medicine Approach. New York: Marcel Dekker, Inc.

Roitt, I.M. (1997). Roitt's Essential Immunology. $9^{\text {th }} \mathrm{ed}$. London: Blackwell Science.

Sattler, J.M. (1992). Assessment of Children, Revised and Updated Third Edition. San Diego: Jerome M. Sattler, Publisher, Inc.

Scott, H., Fausa, O., Ek, J. \& Brandtzaeg, P. (1984). Immune response patterns in celiac disease. Serum antibodies to dietary antigens measured by an enzyme linked immunosorbent assay (ELISA). Clinical and Experimental Immunology, 57, 25-32.

Scott, H., Rognum, T.O. \& Brandtzaeg, P. (1985a). Performance testing of antigen-coated polystyrene microplates for ELISA measurements of serum antibodies to bacterial and dietary antigens. Acta Pathologica Microbiologica et Immunologica Scandinvica - Section C, Immunology, 93, 117-123.
Scott, H., Rognum, T.O., Midtvedt, T. \& Brandtzaeg, P. (1985b). Age-related changes of human serum antibodies to dietary and colonic bacterial antigens measured by an enzyme-linked immunosorbent assay. Acta Pathologica Microbiologica, et Immunologica Scandinvica - Section C, Immunology, 93, 65-70.

Shattock, P., Kennedy, A., Rowell, F. \& Berney, T. (1990). Role of neuropeptides in autism and their relationship with classical neurotransmitters. Brain Dysfunction, 3, 328-345.

Shattock, R. (1995). Can dietary intervention be used successfully as a therapy for autism? In The Autism Research Unit (Ed.) Psychological Perspectives in Autism. Sunderland: Sunderland University Press. pp. 203-206

Statistisk Sentralbyrå. (1984). Standard Classification of Socio Economic Status. Standarder for Norsk Statistikk. Oslo: Statistisk Sentralbyrå.

Statistisk Sentralbyrå. (1989). Norwegian Standard Classification of Education. Standarder for Norsk Statistikk. Oslo: Statistisk Sentralbyrå.

Statistisk Sentralbyrå. (1996). Statistisk årbok 1996. Official Statistics of Norway. Oslo: Statistisk Sentralbyrå.

Steele, J. (1996). Epidemiology: Incidence, prevalence and size of the Down's syndrome population. In B. Stratford and P. Gunn (Eds.). New Approaches to Down Syndrome. London: Cassel. pp. 45-72.

Tetzchner, S., Jacobsen, K.H., Smith, L., Skjeldal, O.H., Heiberg, A. \& Fagan, J.F. (1996). Vision, cognition and developmental characteristics of girls and women with Rett syndrome. Develpmental Medicine and Child Neurology, 38, 212-225.

Thorndike, R.L., Hagen, E.P. \& Sattler, J.M. (1986). Guide for Administering and Scoring, the Stanford-Binet Intelligence Scale: Fourth Edition. Chicago: Riverside Publishing.

Whiteley, P., Rodgers, J., Savery, D. \& Shattock, P. (1997). Preliminary findings from the implementation of a gluten free diet with children with autism and associated spectrum disorders. In The Autism Research Unit (Ed.) Living and learning with Autism. Sunderland: Sunderland University Press. pp. 189-197.

Zagon, I.S. \& McLaughlin, P.J. (1987). Endogenous opioid systems regulate cell proliferation in the developing rat brain. Brain Research, 412, 68-72.

Ziodrou, C., Streaty, R.A. \& Klee, W.A. (1979). Opioid Peptides Derived from Food Proteins. The Journal of Biological Chemistry, 254(7), 2446-2449. 